\title{
A COMPARATIVE STUDY OF SHERPA AND NEPALI LANGUAGE ON THE BASIS OF CASE
}

\author{
Dawa Sherpa Ph.D. \\ Lecturer, \\ Tribhuwan University, \\ Mahendra Ratna Campus, \\ Tahachal, Department of Education Nepali
}

Article DOI: $\underline{\text { https://doi.org/10.36713/epra6016 }}$

\begin{abstract}
Sherpa language spoken by Sherpas, the inhabitants of Himalayan region, falls on Tibeto-Burman language family. While comparing the case grammar of Sherpa language and Nepali language both have similarly types of case and case marker (Bibhakti). Sherpa Subjective case takes [ki] suffix as case marker and Nepali case takes [le]. Sherpa objective case takes [la] suffix as case marker and Nepali case takes [lai]. Instrumental case takes [ki/gi] suffix as case marker in sherpa and Nepali case takes [le/ ba;ta]. Dative case take [la:] as case marker in Sherpa and Nepali case takes [lai]. Ablative case takes [tja:su] as case marker in Sherpa and Nepali case takes [ba:ta/ dek i]. Locative case takes [la:]as case marker in Sherpa and Nepali case takes [ma] and possessive case takes [ki] as case marker in Sherpa and Nepali case takes[ ro/ no/ ko]. Sherpa language and Nepali language are similar on the basis of case grammar study. The sentence structure in Sherpa language is different from Nepali language. There is no gender system in this language. Verbs are not changed on the basis of number either.
\end{abstract}

SPECIAL WORDS: Tibeto-Burman, Sambhota Script, Kham, tan, Linguistic Universal.

\section{INTRODUCTION}

This is a comparative study of Sherpa and Nepali language on the basis of case system with their marker. Case is the relation of nouns with the verb. It is the semantic role of noun phrase in sentences (Yadav and Regmi, 2058: 202). Chomsky talked about linguistic universal in his standard theory. According to Chomsky all the languages of words are similar in their deep level though they are different in surface level (Bandhu, 2066: 179). The case of Sherpa and Nepali language have been studied on the basis of this theory. 'Case' is defined as the grammatical category of nominal group in a sentence (Sharma, 2071: 408). This is the thematic role of nouns with the other words, especially verbs. Case is the relation of nominal groups with verb, which is the core of the sentence. The study aims at studying case system of Nepali language and Sherpa language, spoken by the Sherpas of high Himalayan region. Sherpas are supposed to have come to Nepal from Kham of Tibet. Their Sherpa language falls on Tibeto-Burman language family. This language is written in 'Sambhota Script' (Sherpa, 2007: 1). Tibeto-Burma language family is the second largest language family after Indo-European language family on the basis of speakers in Nepali language of TibetoBurma family are spoken in many countries including Nepal. The main area where Sherpa language is spoken is Himalayan region of Solukhumbu district. Sherpas speakers are scattered in various districts of Mechi, Koshi, Sagarmatha, Bagmati and Janakpur zones. They reached in different countries for tourism, trade, hotel and other employment. Sherpa language has various regional dialects. Young (2000AD) has stated three regional dialects as Khumbu, Solu and Western. This language has its own structure and characteristics. So this is a fullfledged language. Constitution of Nepal guarantees every communities to get basic education in their mother tongue as per the language. The study is fulfil to consolidate this policy and to solve the problems that occur to Sherpa speaker while learning Nepali as language. This study is also helpful for the researcher who are interested in case system of Sherpa language. The word 'Karak' (case) has been formed by joining suffix to the base [kri]. It has been derived from Sanskrit [Karsiti]. Case, in its direct sense, refers to the doer of the action, but technically 'case' 
reforms to the interrelationship between various words in a sentence (Dahal, 2061: 51). In grammar case refers to the relation of verb (both finite and non-finite) with the other words. In a sentence these may be nouns, pronouns adjectives with the verbs case in the relation of these words with the verb. The relation of noun phrases with the verb is 'case' (Awasthi and Sharma, 2057: 223).

The nouns or pronouns that are linked with the verb is case. It is a grammatical category of noun or pronoun that show the relation with the verb. 'Bibhakti' in its literal sense refers to divider. It is a special type of suffix that is attached with other words to give different meanings. Chomsky (1981AD) views that no nouns can be found in sentences without case. So case is the relation of nouns with the verbs. Noun includes pronouns as well (Pokhrel, 2056: 107). Grammatical category 'case' refers to the role or function of nominal in a sentence. It is simple (non-changing) and complex (changeable) (Sharma and Luitel, 2060: 133). 'Bibhakti' is the suffix that is attached to the nouns which are directly related to the verbs.

\section{OBJECTIVE}

The objective of this study is to reach to the conclusion by comparing the case between Sherpa language and Nepali language.

\section{METHODOLOGY OF THE STUDY}

This study has been prepared with regional survey method and library work. It is prepared on qualitative framework. The researcher has selected to male and 10 female Sherpa language speakers from 10 household out of 10 households in Ambung V.D.C. and Jirikhimti V.D.C. of Terhathum district. He has adopted qualitative method for collecting data with the help of MP3 voice recording device as the researcher himself is Sherpa language speaker. Data collection was made with questionnaire and interview. The informants were selected by purposive sampling (CrossWell, 2015: 206). Different articles on Sherpa language, library study are the secondary sources of data. The data has been compared with the case of Nepali language. Descriptive method has been adopted for the analysis and interpretation. Case is the grammatical category of nominal group that show relation with the verb in both the languages. It is the relation of nouns with the other words, especially with the verb (Sharma, 2054: 270).

Case in Sherpa language and Nepali language with their marker (bibhakti) has been shown as follows:

\begin{tabular}{|l|c|c|}
\hline \multirow{2}{*}{ Case } & \multicolumn{2}{c|}{ Case marker Indicators } \\
\cline { 2 - 3 } & Sherpa & Nepali \\
\hline Subjective & {$[\mathrm{ki}]$} & {$[\mathrm{le}]$} \\
\hline Objective & {$[\mathrm{la}:]$} & {$[\mathrm{lai}]$} \\
\hline Instrumental/agent & {$[\mathrm{ki} / / \mathrm{gi}:]$} & {$[\mathrm{le} / \mathrm{ba}: \mathrm{ta}]$} \\
\hline Dative & {$[\mathrm{la}:]$} & {$[\mathrm{laI}]$} \\
\hline Ablative & {$[\mathrm{tja}: \mathrm{su}]$} & {$[\mathrm{ba}: \mathrm{ta} / \mathrm{dek}$ h: $]$} \\
\hline Possessive & {$[\mathrm{ki}:]$} & {$[\mathrm{ra} / \mathrm{na} / \mathrm{ko}]$} \\
\hline Locative & {$[\mathrm{la}:]$} & {$[\mathrm{ma}:]$} \\
\hline
\end{tabular}

The above table shows that Sherpa language and Nepali language are similar in their case and their markers.

\section{SUBJECTIVE CASE}

Subjective case is the relation of noun or pronoun that indicates doer of the doer of the verb (Awasthi and Sharma, 2053: 230). Subject is the noun that refers to the doer of the action. Every verb needs subject. None of the works are hold without subject.

Some of the example of subjective case in Sherpa language.

\begin{tabular}{|c|c|c|}
\hline Sherpa Language & Nepali Language & English Language \\
\hline /Pasangki so sung/ & /pasanle knajo/ & Pasang ate. \\
\hline Pasangtibaki sosung & /Pasanharule $\mathrm{k}^{\mathrm{h}} \mathrm{ae} /$ & The Pasangs ate. \\
\hline /njaki tó somi/ & /maile va:t k ${ }^{\mathrm{h}} \mathrm{aĕ} /$ & I ate rice. \\
\hline /nibaki tó somi/ & /hamile va:t knajəu/ & We ate rice. \\
\hline /K $\mathrm{K}^{\mathrm{h}}$ jorongki ts ${ }^{\mathrm{h}}$ ungma lobu/ & /taile ga:i heris/ & You looked at the cow. \\
\hline$/ \mathrm{K}^{\mathrm{h}}$ jorong tibaki ts ${ }^{\mathrm{h}}$ unma lobuza/ & /timiharule ga:i hereko/ & $\begin{array}{l}\text { You...ve looked at the } \\
\text { cow. }\end{array}$ \\
\hline /tigi laka kjasun/ & /tjasle kam garjo/ & He worked. \\
\hline /titibaki lu lansun/ & /tiniharule git gae/ & They sung song. \\
\hline /tigi laka kja sun/ & /jasle kam garo/ & He worked \\
\hline /ditibaki laka kja sun/ & /tiniharule kam gare/ & They worked. \\
\hline
\end{tabular}


Above examples show that Sherpa language takes [Ki] as a case marker and Nepali language takes [le] as case marker. Sherpa language takes [gi] as case marker in $3^{\text {rd }}$ person singular. Even if the two language differ in $3^{\text {rd }}$ person singular they are similar in other persons as [Ki] in Sherpa language and [le] in Nepali language.

\section{OBJECTIVE CASE}

Generally, objective case is the result of the action. The effect or result of the action by the doer is the object. This is considered as resultant object (Neupane, 2051: 277). The examples of objective case in Sherpa language and Nepali language are as follows

\begin{tabular}{|c|c|c|}
\hline Sherpa Language & Nepali Language & English Language \\
\hline 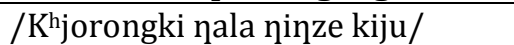 & /taile malai maya gartshas/ & You love me. \\
\hline /nitsa setela ninze longju/ & /niðra sabailai pja;ro la:gts ${ }^{\mathrm{h}}$ / & All like a sleep. \\
\hline /puzjungki nala katansun/ & /tshorale malai bolajo/ & The son called me. \\
\hline /njaki dalzla $\theta$ ansun/ & /maile saӨilai đekhĕ/ & I saw a friend. \\
\hline /papaki mamala tiigal/ & /bubale a:malai lanu vəjo/ & Father took mother. \\
\hline /numa tibaki nəla somun binsun/ & /bəhiniharule məlai topi đIe/ & Sisters gave me a cap. \\
\hline
\end{tabular}

Objective case takes [lai] as case marker in Nepali language and [la:] in Sherpa language. Above examples in both the languages objective case seems similar.

\section{INSTRUMENTAL CASE}

Instrumental case is the role of the noun that has been used as tool to complete the action. To complete the action of the verbs, subject uses some tools, that tool is the instrumental case (Lamsal, 2066: 135).

The examples of instrumental case in Sherpa language and Nepali language are given bellow:

\begin{tabular}{|l|l|l|}
\hline \multicolumn{1}{|c|}{ Sherpa Language } & \multicolumn{1}{c|}{ Nepali Language } & \multicolumn{1}{c|}{ English Language } \\
\hline /njaki k ${ }^{\mathrm{h}}$ urpaki sja tseti/ & /maile $\mathrm{k}^{\mathrm{h}}$ ukurile ma:su/ kate/ & $\begin{array}{l}\text { I cut meat with a machete } \\
\text { knife. }\end{array}$ \\
\hline /ti lakamki sarul setkju u/ & /tjo laurale sarpa martsha/ & That stick kills a snake. \\
\hline $\begin{array}{l}\text { /k } \mathrm{k}^{\mathrm{h}} \text { joronki mjabaki khase } \\
\text { setju/ }\end{array}$ & /taile bandukle mirga maris/ & $\begin{array}{l}\text { You killed a dear with the } \\
\text { gun. }\end{array}$ \\
\hline /na goki laga kirmi/ & /ma buddhile kam gərts ${ }^{\mathrm{h}} \mathrm{u} /$ & I work with intelligence. \\
\hline /na toktsiki sin Komi/ & /ma kođalale bari khənt ${ }^{\mathrm{s}} \mathrm{u} /$ & I dig the field with a spade. \\
\hline
\end{tabular}

In Sherpa language instrumental case has been indicated by [ki] and in Nepali language by [le]. Both Sherpa language and Nepali language has similar structure of instrumental case.

\section{DATIVE CASE}

Dative case is the role of noun in a construction that shows the purpose of the action. In Panani grammar also it has been identified as the purpose of the verb. Each and every work is done with some purpose. Instrumental case refers to the purpose of the verb in a sentence (Awasthi and Sharma, 2053: 95).

The examples of Sherpa language and Nepali language are shown here.

\begin{tabular}{|c|c|c|}
\hline Sherpa Language & Nepali Language & English Language \\
\hline /na knjorongla kitab termi/ & /ma timilai kitab đintsh $\mathrm{u}$ / & I give you a book. \\
\hline /na rala lit ${ }^{\text {si termi/ }}$ & /ma ba:khralai makəi đints ${ }^{\mathrm{h}} \mathrm{u} /$ & I give maize to the goat. \\
\hline /naki đalzala $\theta$ osun/ & /maile saӨilai đekhe/ & I saw a friend. \\
\hline /na knibala tan termi/ & /ma timiharulai pəisa đints ${ }^{\mathrm{h}} \mathrm{u} /$ & I give you money. \\
\hline /na mesila so termi/ & /ma vaisilai ghãs đintsh $\mathrm{u} /$ & I give grass to the buffalo. \\
\hline /na tala litsi termi/ & /ma ghodalai makəi đints ${ }^{\mathrm{h}} \mathrm{u} /$ & I give maize to the horse. \\
\hline
\end{tabular}

In Sherpa language [la:] is the case marker of dative case and in Nepali [lai] is the case marker. These two languages seem similar in dative case as well.

\section{ABLATIVE CASE}

Ablative case is the relation of verb with the subject or object indicating separation, orientation, 
duration, spread and continuity from the fixed entity (Neupane, 2051: 281). Dative case shows the separation of nouns. It shows the separation after the action takes place.

Examples of ablative case from Sherpa language are given below:

\begin{tabular}{|c|c|c|}
\hline Sherpa Language & Nepali Language & English Language \\
\hline /puzung khanba tjasu hungju/ & /ts ${ }^{\mathrm{h}}$ oro gharbata auts ${ }^{\mathrm{h}} \mathrm{a} /$ & The son comes from home. \\
\hline /pum k kettjasu hwasun/ & /ts ${ }^{\mathrm{h}}$ ori khetbata ai/ & The daughter came from field. \\
\hline /nja lakpa tja:su firsun/ & /matsha hatbata uphrijo/ & The fish jumped off the hand. \\
\hline /pumtiwa hartja:su hwasun/ & /tshoriharu bazarbata ae/ & $\begin{array}{l}\text { Daughters came from the } \\
\text { market. }\end{array}$ \\
\hline /Pasan naninn tja:su rambu gal/ & /pasan pohar đekhi motajo/ & $\begin{array}{l}\text { Pasang has got fatter since last } \\
\text { year. }\end{array}$ \\
\hline /niba hambur tja:su hwabuza/ & $\begin{array}{l}\text { /hami Kathmandubata aeka } \\
\text { hãu/ }\end{array}$ & $\begin{array}{l}\text { We have come from } \\
\text { Kathmandu. }\end{array}$ \\
\hline
\end{tabular}

In Nepali language [ðekhi:] and [ba:ta] suffixes are attached to the noun to indicate ablative case and [tja:su:] suffix is attached to the nouns of Sherpa language to indicate ablative case.

\section{POSSESSIVE CASE}

Possessive case shows the possession or ownership of noun (Awasthi and Sharma, 2053: 93). Possessive case indicates the relation of person. Place or thing with the other person, place or thing in a sentence. Possessive case refers to the possession or reference of the noun. Although traditional grammarian considered of as case, this does not show the relation with the verb and therefore, it is not case. Examples of possession in Sherpa language are as follows:

\begin{tabular}{|c|c|c|}
\hline Sherpa Language & Nepali Language & English Language \\
\hline /knjorongki min kəך hin/ & /ti mro nam keho/ & What is your name? \\
\hline /khjorongki k ${ }^{\mathrm{h}}$ amba kani hin/ & /timro ghar kaha ho/ & Where is your house. \\
\hline 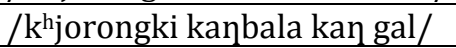 & /tero khutama ke b ${ }^{\text {h}} ә$ jo/ & What happened to your leg? \\
\hline /Nurbuki puzjung lakpa hin/ & /Nurbuko ts ${ }^{\mathrm{h}}$ ora lakpa ho/ & Nurbu's son is Lakpa. \\
\hline
\end{tabular}

In Nepali language [ro], [no] and [kj] is used to indicate possession and Sherpa language case marker used as a [ki]. Nepali language used more case marker in possession case but Sherpa used only [ki].
All the actions take place in some location and time. The place or time on which the event takes place is locative case. Location is the case that shows the place or base of subject and object (Adhikari, 2068: 253).

\section{LOCATIVE CASE}

Some examples of locative case from Sherpa language are given below:

\begin{tabular}{|c|c|c|}
\hline Sherpa Language & Nepali Language & English Language \\
\hline /đongbula tsezinma đesun/ & /rukhma tsara basjo/ & A bird sat on a tree. \\
\hline /đola bu hwa:e/ & /dhunama kira ts ${ }^{\mathrm{h}} \mathrm{a} /$ & There is an insect on the stone. \\
\hline /đan khjoron khangbala hwae/ & /hizo timi gharəim $\theta i j \partial u /$ & You were at home yesterday. \\
\hline /na knetla la:ka kirmi/ & /ma khetma kam gartsh $\mathrm{u} /$ & I work on the farm. \\
\hline /pumatiwa skulla hi loi / & /tshoriharu skulma padtshan/ & The daughters study in school. \\
\hline /Pembaki zholala kitab zjaksun/ & /pembale zholama kitab ra:khjo/ & Pemba put books in the bag. \\
\hline
\end{tabular}

Locative case is indicated as [ma:] suffix in Nepali language and [la:] in Sherpa language.

\section{CONCLUSION}

While comparing the case grammar of Sherpa language and Nepali language they bear similar types of case indicators. Sherpa language takes [ki:] suffix as case marker in the $1^{\text {st }}, 2^{\text {nd }}$ and $3^{\text {rd }}$ person singular takes [gi:] and Nepal language takes [le] suffix as cae marker in subjective case. Objective case takes [la:] as case marker in Sherpa and Nepali takes [lai]. Instrumental case takes [ki:] as case marker in Sherpa and Nepali takes [le/ba:ta]. Dative case takes [la:] as case marker in Sherpa and Nepali takes [lai]. Ablative case takes [tja:su:] as case marker in Sherpa and Nepali language takes 
[ba:ta/đek ${ }^{\mathrm{h}}$ ]. Possessive case takes [ki:] as case marker in Sherpa language and Nepali takes [ro/ no/ ko] and locative case takes [la:] as case marker in Sherpa and Nepali takes [ma]. Bothe Nepali and Sherpa languages use similar case markers, but Sherpa language does not show congruity on the basis of gender, which Nepali language does. There is no change in verb form on the basis of number in Sherpa language. The meaning is distinguished on the basis of tone intonation in Sherpa language.

\section{REFERENCES}

1. Adhikari, H. R. (2068). Pratical Nepali Grammer, lalitpur : Sajha Publication

2. Awasthi, M. and Sharma R. (2053). Nepali Pragmatic Grammer and Expression. Kathmandu: Ekta Books.

3. Creswell, J. W. (2015 A.D). Educational research. India: Pierson Education south Asia.

4. Kuwar, R. R. (1989 A.D.). Fire of himal, An anthropological study af the sherpas of Nepal himalayan region. New Delhi: Niraala Publication.

5. Dahal, D. P. (2061). Dunwari Language: A study. Kathmandu: Sunkoshi Publication

6. Nepal, Government (2072) Nepal's Constitution, Kathmansu: Ministry of law, justice and parliamentary affairs, law books management board Nepal.

7. Neupane, T. P. (2051). Bhasabigyanko ruprekha. Dharan: Nepal book dipo.

8. Pokhrel, M. P.(2056). Nepali sentence grammer. Kathmandu : Ekata books.

9. Bandhu, C. (2066). Bhasabigyan ko Sampradaya . Kathmandu : Ekata books.

10. Brower, B. (1994). Sherpa Of Khumbhu people, livestock, and landscape. New Delhi: oxford University press.

11. Yadav, Y. P. and Regmi B. (2058). Lingusitics. Kathamandu: New Hira books .enterprises

12. Lamsal, R. C. (2066). Nepali language-grammer drama. Kathmandu, inclusive publication and production pvt. ltd.

13. Lee, S. Y. (2000 AD). A socio linguistic survey of sherpa spoken in Solukhumbhu, Ramechhap and Dolakha district of Nepal. Kathamdu: nonpublist survey report, Korean research institute for languages and cultural and royal Nepal academy.

14. Sharma, M. R. (2054). Sabdarachana ra Barnabinyas, Bakyatatwo, abhibyakti ra paathharu. Kathmandu: Nabin publication.

15. Sharma, M. R. and Luitel K. P. (2060).Adhunik Bhasabigyan. Kathmandu: Student book store.

16. Sherpa, P. (2007), The sherpas. Kathmandu: Sherpa kinduk, $U K$.

17. Sherpa, G. (2010 A.D.). Sherpa English-Nepali dictionary. Kathamandu : Sherpa association of nepal.

18. Sherpa, T. L. (1999 AD). The Sherpas and Sharkhumbu. Kathamandu: Nepal lithographing co. pvt.ltd.
19. Sherpa, D. (2058). Sherpa Bhasa ek adhyan. Kathmandu: Nabayug sahakari chapakhana madan Nagar Balkhu. 